\title{
Analysis of Benefits and Costs of Advertising by Manufacturers of Dry Construction Mixes
}

\author{
Valentina Titova \\ Alexander Rymanov \\ Tatiana Titova \\ Novosibirsk State Technical University \\ Email: kafedra-finp@yandex.ru
}

Doi:10.5901/mjss.2014.v5n23p315

\begin{abstract}
The article examines the application of Analysis of Benefits and Costs (ABC) method in evaluating the effectiveness of advertising costs incurred by manufacturers of dry construction mixes. It offers estimates as to how soon spending on advertising of certain product groups translates into an increase in sales. Observations focus on a local producer of dry construction mixes. The analysis has revealed that the actual volume of product sales is influenced by such factors as seasonal patterns, the consumer price index, and advertising. There are discernible cyclical and seasonal fluctuations in combination with a trend component. The article describes the correlation between sales volumes and advertising costs. It also provides estimates as to how soon an increase in advertising costs translates into higher sales. It has transpired that an increase in spending on participation in exhibitions and presentations produces an increase in sales of glue of the Universal brand 1.06 months later on average. Articles appearing in specialist publications produce an increase in sales of glue of the "Superpolymer" brand and the Universal brand 2.1 months and 1.9 months later, respectively.
\end{abstract}

Keywords: Analysis of Benefits and Costs; costing; marketing; dry construction mixture.

\section{Introduction}

Competitive advantages are achievable due to the creation of business models based on the unique satisfaction of needs that should govern the formation of socio-economic strategies of the enterprise, upon which it becomes possible to start developing structural links of the company via selection and focusing its management resources and by balancing them with the planned target results.

A major player in the local market (in Siberia, Russia) as per production of dry construction mixtures is "HerculesSibir" company. Its sector is associated with the activities capable of long-term retain of customers by offering them a value system associated with the sales promotion, outdoor advertising, promotion in the media. The main activities of the company are the production and sales of professional dry construction mixtures (DCM) for indoor and outdoor decoration.

The major competitors of "Hercules-Sibir" on the local market are "PROMEXTEK", "TEKS", "Henkel Bautechnik", "Technology and Materials", "Starateli", "Maska", and "Diola".

\section{Literature Review and Theoretical Background}

For each production company, a periodic assessment of its sales is important. To this end, the Analysis of Benefits and Costs (ABC) is widely used in marketing practice. It helps to assess the contribution of different types of products to achieving the overall profitability of the company (or the contribution by market segments).

The forms of business simulation are varied and depend on the models used and the scope of their application (Abell and Hammond, 1979; Buzzell, 1964; Chetyrkin, 1977; Koshechkin, 2001). Models in marketing are the means for explanation and prediction of the market situation (Doyle, 2009; Khrutsky and Korneeva, 1999; Bocharova, 2014).

The market of dry construction mixtures in its local aspect may be viewed as quite saturated whereas the competition is severe; in general, the situation permits no soon emergence of any new major players in this market. Although the entry barriers are not high, they are difficult to overcome, and therefore there are almost no small firms on this market. 
Dry mixes are easy enough to carry, but the market has its geographic restrictions on transportation too: no more than $500 \mathrm{~km}$. This is due primarily to the fact that dry mixtures, as a rule, are large-sized, but not very high-cost commodity, transportation costs at longer distances increase the product price by some $30-40 \%$.

The market specificity of dry construction mixtures is that about $60-80 \%$ of the products are sold through dealers, regional representatives, and middlemen. To sell the DCM, "Hercules-Sibir" has focused in two segments: wholesale trade (intermediaries); retail sale of DCM (shops, construction supermarkets).

The company "Hercules-Sibir" uses the indirect sales channel predominantly, when the products are sold through a network of shops incorporated into "Kovrovy Dvor" (Carpet Yard) holding.

The main factor of local producers' competitiveness is the price. Providing customers with a wide range of high quality products at the prices lower than the market average, with the broadest set possible of related services, as well as a system of the best offer - these are the basic strategies employed by "Hercules-Sibir".

The correlation of sales and advertising expenditures was found to analyse whether the sales volume is being changed depending on the advertising expenditure (Hamel et al., 1998; Mullin and Cummins, 2008). To this end, the time series of deviations from the trends were calculated, which can be used to obtain the quantitative characteristics of the closeness of relation between the original time series according to the following model:

$Q_{t}=a_{0}+a_{1} X_{t}+u_{t}$

where Qt is the sales of products by "Hercules-Sibir", $X t$ is the advertising cost, $u_{t}$ is a random component.

The ABC of sales is a management tool could be used to identify the key customers, suppliers, products, product groups with the aim of further economic analysis, monitoring and the development of efficient economic decisions (Daly, 2002; Rymanov, 2014). Group A comprises the key products (typically 5 to $20 \%$ of the whole range), which account for more than half of the sales and almost all the profit. Group B means the products which account for a quarter to one third of sales, but the servicing of which brings practically no profit, this group could make up 25 to $60 \%$ of the assortment range. Group $\mathrm{C}$ are the goods which account for a small portion of the sales and the servicing of which brings losses to the company; it could range from 20 to $60 \%$ of all the company's products.

A model with distributed lags and estimate the simulation parameters could be applied to find the response onset to the increase in advertising expenditures:

$$
y_{t}=c_{0}+\sum_{k=0}^{T} X_{k} x_{t-k}+u_{t}
$$

where $T=2$ is the maximum value of lag; $c_{0}$ is the parameter estimation by the method of least squares; $u_{t}$ is a random error.

The parameters according to the following formula were evaluated:

$X k=\Theta(k, a)=a_{0}+a_{1} k+a_{2} k^{2}$

where $a_{0}, a_{1}, a_{2}$ are the parameter estimates obtained by the least squares method.

\section{Results and Discussion}

Analysis and evaluation of the marketing activity by "Hercules-Sibir" was based on the monthly sales and promotion costs. The presence of some seasonality is evident. A surge of sales is in summer - a season of repairs and construction jobs, with its peak in August, as well as on the New Year's holiday.

To assess the marketing activity of enterprise the $A B C$ of the company's products was performed. $A B C$ of 217 commodity items showed that group A includes 5 products ("Universal" adhesive (25 kg), "Superpolymer" adhesive (25 $\mathrm{kg})$, "Rough floor" mixture $(25 \mathrm{~kg})$, Mortar (25 kg), "Unshrinkable" putty (20 kg), "Universal" adhesive (12 kg)), the group B has 23 and the group $\mathrm{C}-189$ products.

Thus, a strategic group of products by the enterprise was defined - group A. The company should pay special attention to any activity related to these goods, constantly use control (monitoring) procedures and promotion planning. Small changes in profitability, turnover, as well as the terms of payment for this group of products can lead to significant changes in the financial result of the company.

Sales of these goods amount to $2.3 \%$ of all products of the enterprise and bring more than $50 \%$ of revenues. This is the most important product group for the enterprise, so further analysis will take into account the impact of advertising on these time series of products bringing the highest profit to the company.

Group B means the goods of the company which have average sales. The leaders in this group, depending on the turnover and the order of importance for the enterprise, can be identified as possible candidates to Group A, with corresponding control provisions. Other products of this group may be attributed to an "average" class with normal control 
procedures.

Group C is usually the most numerous group of products by the enterprise, which is characterized by low sales volumes. With low profitability of sales, operating costs for some products in this group may appear too high. This group has such important indicators are the average and minimum sales. Simplified control procedures are used.

Advertising plays the major role in the market of construction products, contributing to the increased sales. So, we analysed the source data as per spending on advertising by the whole enterprise. To do this, we divided the total advertising expenditures by object of expenditure, namely, articles in specialized publications; outdoor advertising; participation in exhibitions; production of sample products, moulds and product catalogues; development and rental of commercials; the distribution of leaflets and other POS as well as promotional materials.

The actual sales volume of the analysed products by "Hercules-Sibir" is influenced by such factors as seasonality, consumer price index, advertising, and others.

The time series of sales and advertising expenditures were analysed to determine the relationship between the sales volumes and product prices. The correlation analysis is presented in the table (Table 1).

Table 1. The influence of changing the advertising expenditures on sales volumes (significance of F-statistics by the determination coefficients)

\begin{tabular}{|lcccccr|}
\hline \multicolumn{1}{|c}{ Nomenclature } & $\begin{array}{c}\text { Specialized } \\
\text { magazines }\end{array}$ & $\begin{array}{c}\text { Outdoor } \\
\text { advertising }\end{array}$ & $\begin{array}{c}\text { Significance of F models } \\
\text { Exhibitions }\end{array}$ & $\begin{array}{c}\text { Product } \\
\text { catalogues }\end{array}$ & $\begin{array}{c}\text { Commercials in the } \\
\text { media }\end{array}$ & Leaflets \\
\hline "Universal" adhesive, $25 \mathrm{~kg}$ & 0.08 & 0.06 & 0.005 & 0.27 & 0.83 & 0.39 \\
"Superpolymer" adhesive, $25 \mathrm{~kg}$ & 0.05 & 0.73 & 0.13 & 0.08 & 0.96 & 0.46 \\
"Rough floor" mixture, $25 \mathrm{~kg}$ & 0.85 & 0.49 & 0.33 & 0.24 & 0.19 & 0.70 \\
Mortar, 25kg & 0.65 & 0.38 & 0.16 & 0.56 & 0.01 & 0.87 \\
"Unshrinkable" putty, $20 \mathrm{~kg}$ & 0.26 & 0.92 & 0.14 & 0.13 & 0.14 & 0.16 \\
"Universal" adhesive, $12 \mathrm{~kg}$ & 0.05 & 0.10 & 0.63 & 0.29 & 0.49 & 0.94 \\
\hline
\end{tabular}

The relationship between the participation in specialized exhibitions and presentations was found (via selecting the type of advertising for each product set where the significance of F-statistics by the determination coefficients is not greater than 0.05), as well as the impact of printed advertising in the form of magazine articles on the sales growth of adhesive mixtures, especially "Universal" adhesive $25 \mathrm{~kg}$.

Exhibitions affect the sales of adhesives, most likely due to the fact that the adhesives produced by "HerculesSibir" are quite unique in their properties and have almost no analogues in the market, whereas the conduction of presentations and exhibitions helps to spread the information about these properties to the target audience present at such exhibitions. It can be stated that the articles in specialized magazines also affect the sales of adhesives, since the demand for such information is directly requested by the target segment.

The influence of TV and radio ads on the plaster mixtures sales has also been shown, in particular on the mortar $25 \mathrm{~kg}$. The radio advertising campaign was held four times during the analysed period and was focused on promoting the plaster formulations by the company: putties and fillers. The parameter estimates, obtained from the relationship models, are presented in the table (Table 2).

Table 2. The influence of TV and radio advertising on the sales of plaster mixtures (parameter estimates of the relationship models)

\begin{tabular}{|ccccc|}
\hline Indicator & $\begin{array}{c}\text { Universal adhesive }(25 \\
\mathrm{kg}) / \text { exhibitions }\end{array}$ & $\begin{array}{c}\text { Plaster mix (25 } \\
\mathrm{kg}) / \text { commercials }\end{array}$ & $\begin{array}{c}\text { "Superpolymer" adhesive }(25 \\
\mathrm{kg}) / \text { professional magazines }\end{array}$ & $\begin{array}{c}\text { Universal adhesive }(12 \mathrm{~kg}) / \\
\text { professional magazines }\end{array}$ \\
\hline$a_{0}$ & 21.36 & -146.71 & 136.88 & -27.41 \\
$a_{1}$ & 0.04 & 0.02 & 0.008 & 0.001 \\
$\begin{array}{c}\text { P-value of } \\
X_{0}\end{array}$ & 0.97 & 0.65 & 0.79 & 0.792 \\
$\begin{array}{c}\text { P-value of } \\
X_{1}\end{array}$ & 0.004 & 0.01 & 0.05 & 0.052 \\
\hline
\end{tabular}

Based on those estimates, it can be concluded that the value of ao parameter showing the value of corresponding sales at advertising expenditure equal to zero, in all models does not have any economic substantiation, because the P-values for 
all the parameters exceed 0.05 . Therefore, it can be concluded with a probability greater than 0.95 that all the parameters are not significant and can be neglected. With regard to the value of $a_{1}$ parameter, it shows the average change in response to changing the regressor by one unit. That is, the increase in participation in the exhibitions and presentations by 1000 roubles (EUR 20.9) will increase the sales of Universal adhesive $(25 \mathrm{~kg})$ by 40 packages. Increase in the cost of placement of commercials on TV and radio by 1000 roubles has increased the sales of plaster mixtures $25 \mathrm{~kg}$ by 20 pieces. Articles in specialized magazines have evoked the increase in sales of "Superpolymer" adhesive (25 kg) and Universal adhesive (12 kg) by 8 and 1, respectively, while increasing the costs by 1000 roubles.

The average response changes while changing the regressor by one unit. That is, if we increase the cost of participation in exhibitions and presentations by 1000 roubles, it will increase the sales of Universal adhesive $25 \mathrm{~kg}$ by 40 pieces. Increase in the cost of placement of commercials on TV and radio by 1000 roubles will cause an increase in sales volume of plaster mixtures $25 \mathrm{~kg}$ by 20 pieces. Articles in specialized magazines caused the increase in sales of "Superpolymer" adhesive $25 \mathrm{~kg}$ and Universal adhesive $12 \mathrm{~kg}$ by 1 and 8 packages, respectively, while increasing the costs by 1000 roubles.

\section{Conclusion}

It was found that the response to the increase in the cost of participation in exhibitions and presentations would cause the response in "Universal" adhesive $25 \mathrm{~kg}$ sales, on the average, in 1.06 months. The response to the increase in the cost of advertising on TV and radio has caused a slight response in the sales of plaster mixtures $25 \mathrm{~kg}$. Since all P-values are greater than 0.05 , then $\mathrm{H}_{0}$ hypothesis is rejected at the $95 \%$ level of significance, that is, all the parameters are insignificant, they can be ignored, and therefore the corresponding regressors in the model do not affect the response.

Articles in professional magazines evoked the response and the increase in the sales of "Superpolymer" adhesive $25 \mathrm{~kg}$ and "Universal" adhesive $12 \mathrm{~kg}$ in 2.1 and 1.9 months, respectively.

The main lever of marketing in successful sales is development of the distribution network. The main methods of sales promotion will be discounts, POS materials, and skill level of the sellers. A well-planned and carried out demonstration of the benefits of the products may become a major facilitator in the promotion of goods.

\section{References}

Abell, D. K. and Hammond, J.S. (1979). Strategic Market Planning. Englewood Cliffs, NJ: Prentice-Hall.

Bocharova, I. (2014). Benchmarking corporate governance for emerging markets. Actual Problems of Economics, 153 (8).

Buzzell, R.D. (1964). Mathematical models and marketing management. Boston: Division of Research, Graduate School of Business Administration, Harvard University. 281 p.

Chetyrkin, E.M. (1977). Statistical forecasting methods. Statistika.

Daly, J.L. (2002). Pricing for profitability: activity-based pricing for competitive advantage. John Wiley \& Sons.

Doyle, P. (2009). Value-based Marketing: Marketing Strategies for Corporate Growth and Shareholder Value. John Wiley \& Sons, 380 p.

Hamel, G., Prahalad, C. K., Thomas, H., and O'Neal, D.E. (1998). Strategic Flexibility: Managing in a Turbulent Environment. John Wiley $\&$ Sons, $416 p$.

Khrutsky, V.E. and Korneeva I.V. (1999) Modern marketing: Market Research. Finance and Statistics.

Koshechkin, S.A. (2001). Sales volume forecasting algorithm in MS Excel. Marketing in Russia and abroad, 5: 34-42.

Mullin, R. and Cummins, J. (2008). Sales Promotion: How to Create, Implement and Integrate Campaigns that Really Work. Kogan Page Publishers, $300 \mathrm{p}$.

Rymanov, A. (2014). Public procurement methods in Russia. Actual Problems of Economics, 153 (8). 